\title{
Histórias de Gatos Livres na Literatura Infantil de Sylvia Orthof
}

\author{
Free cat stories at children's literature of Sylvia Orthof \\ Kelly Cristina Medeiros Ferreira* \\ *Universidade Federal do Ceará, UFC, Fortaleza - CE, 60020-181, \\ e-mail: kelly_mferreira@yahoo.com.br
}

\begin{abstract}
Resumo: Sylvia Orthof (1932-1997) consagrou-se como uma das mais importantes escritoras da literatura infantil brasileira. Entre suas temáticas recorrentes, os animais não humanos figuram em profusão, assim sendo, este estudo objetiva verificar a destacada presença dos gatos na obra da autora arrolada, e mais especificamente os bichanos não domésticos vivenciando momentos de especial cumplicidade com outros seres não humanos. Para tanto, realiza a análise dos seguintes textos zooliterários - o conto de animais História engatada e da fábula poética Gato pra cá, rato pra lá. As formulações críticas e teóricas, nomeadamente, de Jacques Derrida (2011) e (2003), Nelly Novaes Coelho (1991) e Fanny Abramovich (1999) fundamentam a leitura.

Palavras-chave: Literatura Infantil. Sylvia Orthof. Gato.
\end{abstract}

\begin{abstract}
Sylvia Orthof (1932-1997) was consecrated as one of the most important writers of Brazilian children's literature. Among their recurrent themes, nonhuman animals appear in profusion, so this study aims to verify the outstanding presence of cats in the author's work, and more specifically nondomestic pussies experiencing moments of special complicity with other nonhuman beings. To do so, he analyzes the following zoological texts - the animal tale História engatada and the poetic fable Gato pra cá, rato pra lá. Critical and theoretical formulations, in particular, by Jacques Derrida (2011) and (2003), Nelly Novaes Coelho (1991) and Fanny Abramovich (1999) base the reading.

Keywords: Children's Literature. Sylvia Orthof. Cat.
\end{abstract}

Por que permanecem, se acomodando com suas preguiças sucessivas, se o imoderado amor é que os faz sair e percorrerem os quarteirões?

(Guimarães Rosa)

\section{A QUESTÃO ANIMAL E A LITERATURA}

Sylvia Orthof (1932-1997) escreveu mais de cento e vinte títulos literários infantis e infanto-juvenis em gêneros diversos - contos, poesia e teatro - e estabeleceuse como uma das mais expressivas escritoras infantis brasileiras recebendo, entre outros, mais de treze prêmios com o selo Altamente Recomendável para Crianças pela Volume 20

Número 47 


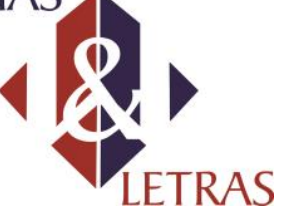

Fundação Nacional do Livro Infantil e Juvenil. Tendo em vista a forte presença dos animais não humanos na escritura orthofiana, este artigo tem por objetivo observar a ampla presença dos gatos na literatura zooliterária infantil da autora pautada através da apreciação do conto de animais História engatada e da fábula poética Gato pra cá, rato pra lá.

Antes de adentrar no escopo do trabalho - a representação de gatos livres travando marcantes experiências ao lado de outros animais em obras orthofianas - tornase oportuno tecer algumas breves considerações sobre o contexto no qual essa questão insere-se. Destarte, essa seção busca trazer alguns subsídios que reportem à conjuntura maior do corpus da pesquisa, como o tratamento da questão animal, maiormente, na literatura.

A representação dos animais não se limita à literatura infantil ou infanto-juvenil, sobretudo, nos gêneros conto e fábula. Antes, trata-se de uma temática que acompanha o homem desde os tempos mais remotos. Sendo assim, na vasta arca religiosa e cultural humana os animais comparecem desde os primórdios. A partir desse ponto, surgiram em textos variados de diferentes povos que construíram o próprio panteão animal de acordo com a fauna que os cercava e/ou com o imaginário popular. Provavelmente, as primeiras divindades eram zoomórficas.

Mais tarde, com o refinamento das estratégias da caça e da pesca e o estabelecimento do domínio sobre as feras surgiram as antropomórficas. Na mitologia egípcia, Bastet, Bast ou Ubasti era a deusa da fertilidade e protetora das mulheres, possuía o corpo de mulher e a cabeça de gato. A respeito do antropozoomorfismo, a mitologia grega comporta do mesmo modo uma galeria de seres híbridos que ensejam na própria compleição uma profunda simbiose entre animais humanos e não humanos.

Jean Chevalier (2009, p. 57-59) em Dicionários de símbolos registra que os animais não humanos que tão usualmente intervêm nos sonhos e nas artes, compõem identificações parciais com o homem; aspectos, imagens de sua natureza complexa; espelhos de suas pulsões profundas, de seus instintos domesticados ou selvagens. Cada um deles corresponde a uma parte do homem. Ou ainda, o animal em sua qualidade arquetípica representa as camadas profundas do inconsciente e do instinto.

A aparição do animal não se restringe ao campo artístico, mas essa parece ser um reflexo da história natural na qual comparece na marcha comum ao homem, seja em cooperação ou competição. Assim, vinculam-se comunitariamente ou paralelamente. Cientificamente, também eles se apresentam, por exemplo, na filosofia que se ocupou Volume 20 


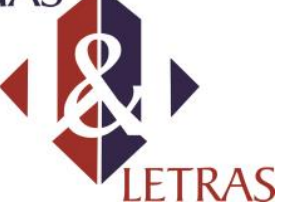

deles ao longo dos tempos. Assim, na era moderna com a ascensão do pensamento cartesiano, a partir do século XVII, o animal passou a ser visto como máquina, indiferente ao sofrimento, um corpo sem alma ou ainda um simples mecanismo, passando a ser cada vez mais examinado pela ciência seja para observação ou experimentação.

Ampliou-se, desse modo, a distância entre o homem e animal, os quais se aproximavam na antiguidade pela ideia de que ambos encerravam em seus corpos uma alma, tanto em Platão como em Aristóteles. Hegel também contribuiu para aumentar o abismo entre humanos e não humanos, no século XIX, ao recuperar a consciência como espírito, ou seja, o desenvolvimento de uma atividade mental que permite estar no mundo com algum saber ou com ciência, daí a designação sapiens sapiens: o ser que sabe que sabe. O animal, para o filósofo alemão, sabe, todavia, não sabe que sabe: de outro modo, teria multiplicado invenções e desenvolvido um sistema de construções internas.

Sobre os gatos, motivo dessa investigação, a relação do homem com os bichanos reporta à Antiguidade, registros encontrados no Egito, indicam que tal relação iniciou-se há cerca de 9.500 anos. A intensidade do afeto dos egípcios por esse animal fez com que se promulgassem leis proibindo sua exportação. A violação da lei era punida com a morte, além disso, quem matasse um gato também receberia a mesma sentença. Contudo, não tardou para que a efetivação do transporte clandestino se realizasse para outros territórios, ocasionando a abrangência da área de alcance desses animais como também sua veneração, tal como ocorreu, por exemplo, na Pérsia.

Devido ao fato de serem exímios caçadores e auxiliarem no controle de pragas, por muitos séculos, os gatos ocuparam uma posição privilegiada na Europa cristã. Porém, no início da Idade Média, a situação alterou-se e os gatos passaram a ser acusados de associação a maus espíritos e, por isso, muitas vezes, foram queimados juntamente com as pessoas acusadas de práticas heterodoxas pelos tribunais inquisitoriais. Por causa de um simbolismo bastante heterogêneo, a visão acerca do gato "oscila entre as tendências benéficas e maléficas, o que se pode explicar pela atitude a um só tempo terna e dissimulada." (CHEVALIER, 2009, p. 461).

Portanto, a temática dos animais, e especialmente a dos gatos, assume ao longo da história humana conotações polissêmicas o que denota a dificuldade em instituir uma noção clara do que seriam esses seres adorados, temidos, estigmatizados e caçados. No campo literário, diversos escritores debruçaram-se sobre o animal, esse outro e no que 


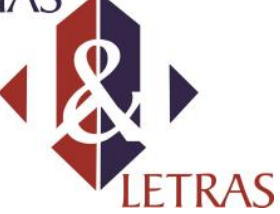

diz respeito ao gato, entre tantos, destacam-se Charles Dickens, Edgar Alan Poe, James Joyce, Doris Lessing, Ernest Hemingway, Patrícia Highsmith, Jorge Luis Borges, Julio Cortázar e Guimarães Rosa.

Trazendo a discussão para o campo da literatura brasileira, lancemos luz sobre Guimarães Rosa (1908 - 1967). Para o escritor mineiro, os animais possuem alma e a admiração e o respeito que inspiram, transparecem em sua escritura através de um notável processo de sublimação. Em 'Circo do mundinho', texto de Ave palavra, Rosa (2009, p. 1124-1127) elabora uma bela crônica-fábúla poética sobre grilos, louva-adeus, cigarras e sua gata Xizinha. No dia 17 de janeiro à tarde, mais precisamente às seis e trinta de um ano impreciso, dá-se de repente o assanhamento de cigarras à janela do cronista que se põe a ouvi-las. E com todos os sons possíveis elas se expressam "em crescendo. Em vários níveis. Tantos esses, no febril! Cada uma é um ponto de laminação carretel, vapor, fervor, orifício." O cronista as define como "os galos da tardinha" e manifesta conhecimento sobre a espécie ao afirmar que apenas os machos produzem som através "dos abdomes membranosos; o cio, cio, cio".

Após o concerto, apenas uma permanece, trata-se de uma cigarra "trissílaba. É uma cigarra frigideira. Mas paroxística. Uma cigarra que até cacareja. Quando ela pára, dói na gente. Vai-se até ao coraçãozinho dela, dentro de um susto.” O dito bicho, de certa feita, foi parar nas patas da gata, mas como ela "grinchava de horror. Doida, fortemente, estridulantérrima. Era um alarme terrível. Nenhum bicho se defende mais braviamente a brados, nem pede tão endiabrado socorro", (ROSA, 2009, p. 1126-1127) o cronista decide salvá-la e por um instante a teve fremente nas mãos e

Essa era como as outras: a grossa cigarra de asas escritas, asas nervosas, vertical - feia, bela, horrenda. Cigarra de ferro, renha cigarra; como a beleza de teus sons te envolve!

Nem me agradeceu. Perguntei, repreendendo-a:

- Por que você grita tão exagerada?

E:

- O SENHOR NÃO ACHA QUE A VIDA MESMA É QUE UM EXAGERO? - foi sua terminante resposta. (ROSA, 2009, p. 1127)

O cronista após retirar o inseto das leves garras de Xizinha, trava um diálogo imaginário com o bicho de aspecto indecifrável ou de difícil conceituação, pois é belo e horrendo assim como o som produzido pode ser. Ao interpelá-la sobre o exagero de sua vocalização, ela retruca em letras garrafais, o que poderia denotar a diferenciação de sua fala em relação à linguagem humana ou ainda à intensidade de sua resposta. Assim, no 


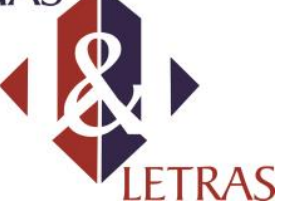

esforço de sondar - pelos poderes da imaginação - a subjetividade desse outro que é o animal e estabelecer com ele uma relação de cumplicidade ou de devir, Guimarães Rosa constrói em Ave, palavra o seu bestiário particular. Sejam os animais habitantes dos zoológicos do mundo ou dos aquários, dos jardins, do riacho Sirimim, ou ainda, os bichos domésticos, todos adentram na esfera do poético de sua escritura em prosa ou verso.

Verdadeiro bestiário constrói também as literaturas oral, de cordel, infantil e infanto-juvenil, todas consideradas, o mais das vezes, menores em relação à literatura sopesada como maior (aquela que não precisa de adjetivos). Restringindo ainda mais a investigação e conduzindo-a para o campo da literatura infantil, Nelly Novaes Coelho (1991, p. 24) em Literatura Infantil - teoria, análise, didática alerta que esta "é antes de tudo, literatura, ou melhor, é arte, fenômeno de criatividade que representa o Mundo, o Homem, a Vida, através da palavra. Funde os sonhos e a vida prática; o imaginário e o real; os ideais e sua possível/impossível realização..."

No interior da literatura infantil brasileira, a larga produção artística de Sylvia Orthof, tão díspare ao comportar uma diversidade de gêneros, temas e personagens, insere-se nessa senda de representação amalgamando fantasia e realidade com humor. No entanto, o humor não distancia o leitor da reflexão frente ao mundo, antes tende a aproximá-lo. Acrescente-se ainda que a literatura orthofiana ao lidar com preconceitos e estereótipos termina por desconstruí-los por meio do riso ou do encanto que uma dada situação pode proporcionar.

Marcia Andrade Morais Cabral (2017, p. 168) na conclusão de sua tese intitulada Semiótica e argumentação: análise das obras de literatura infantil de Sylvia Orthof ao tratar da relação enunciador e enunciatário ressalta o riso como "componente basilar da interação" e que "a lógica discursiva baseada na concessão arrebata o sujeito pelo sobrevir", além disso, anota que "todo estilo possui um viés sensível” e que "o estético e o estésico não se excluem". Tendo em vista, que o humor já foi amplamente observado e pesquisado, propomos nesse artigo evidenciar o estésico da escritura orthofiana.

Entre as temáticas recorrentes na literatura de Sylvia Orthof destacam-se a recuperação dos contos de fadas - Uxa, ora fada, ora bruxa (1985), Ervilina e o Princês (1986), Manual de boas maneiras das fadas (1995), Fada Fofa em Paris (1995), Fada Fofa e os 7 anjinhos (1997), Fada Fofa e a Onça-Fada (1998) e A Fada Sempre-Viva e a Galinha-Fada (1986), A bruxa Fofim (2002), Fada Cisco-Quase-Nada (1992) - e a Volume 20 


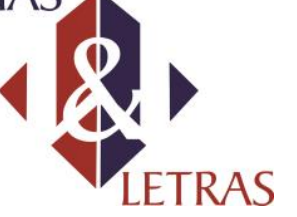

e-ISSN: 1981-4755

representação da velha - A limpeza da Teresa (1983), A velhota cambalhota (1986), As visitas de dona Zefa (1998), Tia Carlota tricota e tricota (1994), Uma velha e três chapéus (1986), Vovó viaja e não sai de casa (1994).

Outra temática proeminente diz respeito à figuração dos animais que aparecem em superabundância, como os seguintes: a) bichos pequeninos do céu ou da terra - Tem minhoca no caminho (1995); Mas que bicho lagarticho (1996); Tumebune, o vaga-lume (1989); b) animais silvestres - Dita-Cula, a coruja (1987); Malandragens de um urubu (2002); No fundo do fundo, lá vai o tatu Raimundo (1984); c) imaginários - Dragonice diz-que-disse (2004), Zoiudo, o monstrinho que bebia colírio (1990); d) de criação Galo, galo, não me calo! (1992); Foi o ovo?Uma ova! (1990); Fraca, fracola, galinha d'Angola (1993); Moqueca, a vaca (1999); História avacalhada (1986); Vaca Mimosa e a mosca Zenilda (1982); Maria vai com as outras (1982); e) de estimação - História Vira-lata (1997); Canarinho, cachorrão e a tigela de ração (1994); Os bichos que tivememórias zoológicas (1983).

\section{OS GATOS EM OBRAS DE SYLVIA ORTHOF}

Em meio a tal diversidade de animais na obra zooliterária de Sylvia Orthof, realcem-se nesse ponto, os gatos. E entre os famosos da literatura infantil destacam-se o Gato de Botas ou Gato Mestre e sua astúcia; Gato Cheshire e seu sorriso enigmático; Gato Malhado e seu amor impossível pela andorinha Sinhá. A estes bichanos vinculamse os singulares gatos orthofianos. Iniciemos o percurso de leitura com Uma história de telhados, O sapato que miava e Os bichos que tive.

Uma história de telhados, publicado em 1981, narra um encontro entre um "gato tigrado, riscado de cinza claro e cinza escuro" (ORTHOF, 2012b, p. 09), um menino e uma velha que viajando por telhados experimentam novos olhares e perspectivas. Os três personagens aproximam-se, pois tinham interesses e/ou características em comum, o gato e o menino pareciam querer um amigo e a velha "era velha por fora e criança por dentro" e "sem certos e errados como a maioria das gentes grandes" (ORTHOF, 2012b, p. 13).

A intensa presença da velhice na escritura orthofiana configura-se como mais um meio de quebrar expectativas, pois se retrata tal fase de modo não convencional, assim, as personagens vivem situações e formulam pensamentos inesperados. $\mathrm{O}$ trio, composto Volume 20

Número 47 


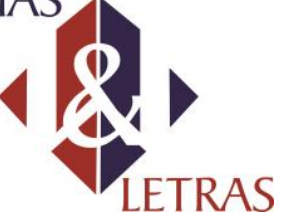

por seres dotados de sabedoria, espectadores e atores de um mundo em devir, passa por momentos extraordinários. Um exemplo da desconstrução orthofiana pode ser observado no fragmento abaixo:

No apartamento da velha, tinha uma gaiola aberta, sem passarinho.

- Cadê o passarinho da gaiola?- perguntou o menino.

- Passarinhos não são das gaiolas, passarinhos são das asas respondeu a velhinha, que escancarou ainda mais a porta da gaiola. Aí, aconteceu uma coisa deveras misteriosa: quando a velhinha tocou na gaiola, a gaiola começou a cantar. (ORTHOF, 2012b, p. 16)

A passagem acima remete ao gosto pela liberdade e pelo imprevisto da escritura de Orthof, aqui em relação aos animais. Já $O$ sapato que miava foi publicado em 1988 e conta que Dona Velha tinha um "gato bem gatinho era um gato riscadinho chamado gato Deodato" (ORTHOF, 2007, p. 4) que dormia em seu grande e velho sapato. Um dia, ela resolve ir à feira e calçando o sapato, não nota que Deodato está lá todo espremido e sofrendo com o chulé. Todavia, o cachorro de um velhinho passa a perseguir o gato. A correria se instala:

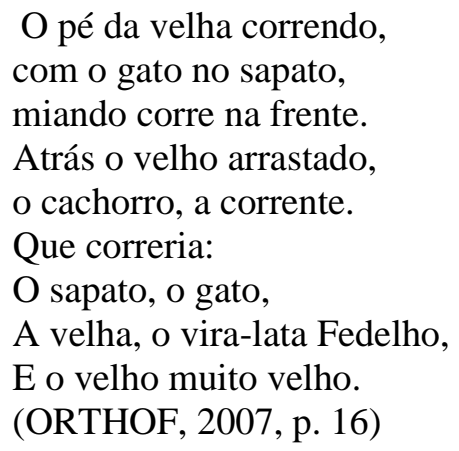

Mas no final "se não me falha a memória, acabou assim, assado: o velho casou com a velha na igreja do povoado. Muita gente foi pra festa, muito bicho foi também." (ORTHOF, 2007, p. 18). E o casal passou a morar na velha casa de Dona Velha. O gato continuou a dormir no sapato da dona e o cachorro dormia no chinelo do dono. As alegres ilustrações de Ivan Zigg, vencedor do prêmio Jabuti em 2004, complementam ora a monotonia, ora a movimentação da trama. Ao fim, o gato e o cachorro, alcançando o certo por meio do incerto, conduziram os velhos para uma existência mais realizada.

Por sua vez, Os bichos que tive - memórias zoológicas, publicado em 1983, divide-se em oito episódios e cada qual retrata bichos diferentes da infância de Sylvia Orthof desde uma rã, um coelho, um bicho-de-pé, um cachorro bassê, um elefante, um bicho-papão, uma gata e um bicho-carpinteiro. O sétimo episódio traz à baila a gata Clementina. Essa é uma personagem limítrofe de nosso recorte temático e merece maior 


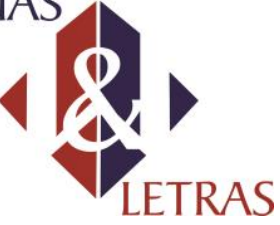

atenção, pois a despeito de ser considerada de estimação, a mesma possui uma natureza não domesticada: “... era uma gata de telhado, dessas gatas listradas. Vivia namorando, miando e tendo filhotes. Mas era mais para namoradeira do que para mamadeira." (ORTHOF, 2004, p. 61).

Trata-se de uma bela história sobre a relação do cachorro bassê que se tornou babá dos gatinhos por causa da negligência da mãe. Sylvia Orthof, fazendo uso da imaginação em um processo semelhante ao de Guimarães Rosa em "Circo do mundinho", reproduz em certo momento de seu texto memorialístico o diálogo entre os animais mencionados:

- Clementina! Au, au, já pra dentro, mãe desnaturada! Seus filhos precisam mamar!

- Miau! Que cachorro chato! Vai cuidar da sua vida, que estou no portão, esperando um gatão, chamada Gastão!

- Au, au! Você é muito ingrata, sua gata! Fico dia e noite deitado na cesta, cuidando dos seus gatinhos. Cuido dos horários da mamada, dou banho neles, e você só fica no portão, esperando um gatão chamado Gastão?

[...]

De repente, Bobby perdia a paciência. Avançava em Clementina, que saía correndo, empurrada, até a cesta. Quando Clementina chegava na cesta, os gatinhos avançavam, nhoc, nhoc, cada um numa teta de Clementina, e mamavam, mamavam, até dormir. Clementina gostava dos filhos, é claro, mas era gata de telhado, não podia ver um gatão, se enronronava toda! (ORTHOF, 2004, p. 62)

O texto apresenta uma grande riqueza de possibilidades de análise, a proximidade da relação entre o cachorro e a gata descritos acima enternece. O texto trata ainda sobre a morte de Clementina:

... um dia, aconteceu uma coisa triste: Clementina foi atravessar a rua, não olhou com atenção, foi atropelada e morreu.

Bobby, que tinha ido ao portão pra chamar Clementina pra atender os gatinhos, viu tudo, compreendeu tudo. Sentou num canto, chorou aquele choro de cachorro triste, pois apesar das brigas, Bobby e Clementina eram amigos.

(ORTHOF, 2004, p.62)

Fanny Abramovich (1999, p. 111) em Literatura infantil - gostosuras e bobices sobre tal tema afirma que sua representação na literatura constitui-se um caminho pouco explorado "como se a morte não fizesse parte da vida, como se a criança não se defrontasse com ela...". Na narrativa em pauta, a morte que não exclui sofrimento e saudade é, em parte, solucionada pela brilhante atuação de Bobby que traz uma gata branca gorda com seus três filhotes para a casa e ela "virou a mãe de todos". "Mãe de todos ficou sendo o nome da gata." (ORTHOF, 2004, p. 66). Bobby e Clementina 


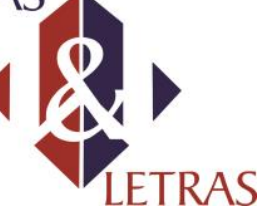

formavam uma admirável parceria e essa imprevista sociedade demonstra outra forma de desconstrução de Orthof. Gê Orthof elegeu uma cor contrastante para compor com o preto as ilustrações de cada episódio do livro. Tal opção oferece maiores possibilidades de interpretação, pois a economia do traçado possibilita imaginar as cenas descritas.

O gato de Uma história de telhados apesar de ser de telhado, apresenta-se em companhia de humanos. Já os bichanos de $O$ sapato que miava e Os bichos que tive são considerados de estimação. Logo, não adentram na delimitação ou escopo da pesquisa descrito(a) anteriormente. Procedamos, assim, a leitura de História engatada e Gato pra cá, rato pra lá.

Publicada em 1997, História engatada conta a terna história de "um gato, dois gatos que viraram três" (ORTHOF, 2000, p. 2-4). Dois gatos se encontraram, se gostaram e à noite se casaram. Ele tinha listras horizontais e ela possuía listras verticais. Pouco depois nasceu um gatinho xadrez. As ilustrações da premiada escritora e ilustradora Eva Furnari que recebeu o Prêmio Jabuti, nos anos de 1986, 1991, 1993, 1995, 1998 e 2006, dão o tom engraçado e leve que as peças de Sylvia Orthof possuem. As ilustrações inauguram uma relação intersemiótica que conduz a duas leituras possíveis que dialogam entre si - a visual e a verbal.

A partir de Monteiro Lobato (1882-1948) em cuja obra o humor se firma como presença constante, inaugura-se um novo olhar sobre a escrita destinada aos leitores iniciantes, ou, inicia-se de fato a literatura infantil brasileira. Coelho (1999) considera Lobato o divisor de águas que separa o Brasil de hoje e de ontem no que concerne às obras destinadas às crianças. Ele rompeu definitivamente com as convenções passadistas e estereotipadas e acabou por influenciar também outros escritores brasileiros, principalmente os contemporâneos que foram seus leitores na infância, como, por exemplo, Ruth Rocha, Ana Maria Machado, Lygia Bojunga e Sylvia Orthof.

As histórias a partir de Lobato passam a apresentar o nonsense, o cunho rebelde e a moralidade conformista perde seu monopólio. Orthof, na esteira lobatiana, rompeu a tradição de produzir uma literatura de cunho pedagógico, doutrinário, moralista ou nacionalista de sorte que em sua obra o certo e o errado se atravessam e quebram a antiga dicotomia. Assim, em História engatada não há tom doutrinário ou nacionalista e os códigos verbal e visual se complementam e mostram cenas de um relacionamento - o encontro, o namoro, o casamento e a chegada do terceiro membro. A ilustração revela, por exemplo, a transformação no corpo da gata por causa da espera do filhote. 


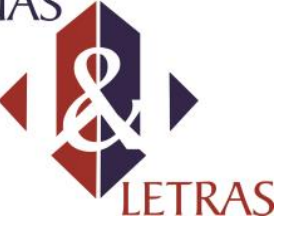

O conto de animais e a fábula História engatada e Gato pra cá, rato pra lá empregam a subversão, pois enfatizam a fluidez e a transferência de traços entre animais humanos e não humanos. Nesse sentido, o núcleo do enredo do conto em análise consiste em mostrar um relacionamento que passa por várias fases até culminar com a reprodução da espécie. A escritura de Orthof fala menos nesse sentido do que as ilustrações de Lima que antropomorfizam mais o texto. O espaço da zooliteratura pode ser compreendido como uma troca constante entre os dois polos até a conversão final e radical do olhar animal sobre o humano. Tais narrativas tendem a relacionar o homem e animal de modo não hierárquico, mas imbricados numa rede de diferentes interconexões, como revelam os trechos finais de História engatada:

$$
\begin{aligned}
& \text { O gato e a gata } \\
& \text { se viram e miaram. } \\
& \text { Subiram nas casas } \\
& \text { Miando... E gostaram. } \\
& \text { Casaram de noite, } \\
& \text { como os gatos se casam. } \\
& \text { E nasceu um gatinho } \\
& \text { dos gatos listrados. } \\
& \text { As listras deitadas } \\
& \text { e as listras pra cima, } \\
& \text { formaram um gatinho, } \\
& \text { o número três: } \\
& \text { que gato engraçado, } \\
& \text { é um gato xadrez! } \\
& \text { (ORTHOF, 2000, p. 9-15) }
\end{aligned}
$$

A rede intercambiável de relações entre a animalidade e a humanidade torna-se ainda mais visível nos trechos finais que destacam o encontro, o casamento e o nascimento do filhote. Orthof não subestima seu leitor, por isso oferece-lhe o exercício de pensar, refletir.

Sobre o estilo de Sylvia Orthof, Abramovich (1999, p. 59) escreve sobre a leveza do verso, da rima, do ritmo e da cadência das frases. "Inesgotável na sua imaginação, na sua quebra de expectativas, de estereótipos, de formas outras de perceber o que quer que seja." O estilo leve e coloquial de Orthof aproxima-a do público infantil assim como as ilustrações divertidas e coloridas de Eva Furnari. História engatada permite um olhar múltiplo, pois se percebe o mundo com os olhos do autor, do ilustrador e do leitor; todos enxergando de modos distintos. Esse sentido, a visão, pode contribuir para a não formação de leitores míopes às tantas possibilidades de perceber o entorno de forma descondicionada e criativa. 


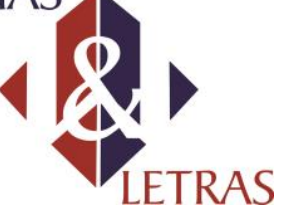

Querer saber de todo o processo que acontece do nascimento até a morte faz parte da curiosidade natural da criança, pois se trata da vida em geral e da sua própria existência. Para Abramovich (1999, p. 99-100), qualquer tema deve ser tratado com verdade, sentimento, vivência e clareza por parte do autor "senão vira uma pincelada demagógica, nada esclarecedora, para quem lê." Logo, o tratamento do tema não deve ocorrer de "modo mascarado, maquilado ou pretensamente facilitado". A literatura infantil, a exemplo dos contos de fadas, pode falar de revelações, de sexualidade, da vida, da morte, dos ciclos que se iniciam e se fecham.

No que diz respeito ao título Gato pra cá, rato pra lá, publicado em 1984, Carlos Drummond de Andrade elaborou a seguinte descrição: “é das fábulas poéticas mais encantadoras que já vi. Exala afetividade, graça, compreensão ideal da vida." De fato, a fábula poética em questão reveste de sensibilidade um encontro entre um gato e um rato que se encaminhava para um triste desfecho. Todavia, intervenções externas e internas modificam o percurso narrativo e abrem espaço para novas possibilidades de convivência, ou reportando a Drummond “à compreensão ideal da vida”. Trata-se de um breve texto rimado que alcança maior expressividade com as ilustrações da premiada Graça Lima que recebeu o prêmio Jabuti em 1982, 1984 e 2003.

O texto em pauta inicia-se com os seguintes versos: "Era um gato, muito viajado,/ que andava pulando sobre o telhado/ e encontrou, de repente, de cinza vestido,/ um ratinho choroso que estava perdido." (ORTHOF, 2012a, p. 7-9). A ilustração apresenta um gato preto passeando pelos telhados, tal aparição usualmente pressagia um mau agouro. Já o rato cinza da ilustração contrasta com o gato, ao passo que este aparenta grandeza e segurança aquele somente perpassa pequenez e insegurança.

Chevalier (2009, p. 462-463) observa que em muitas culturas o gato preto simboliza a obscuridade e a morte. Também se acredita que possui qualidades mágicas e por isso utiliza-se seu sangue para escrever palavras encantatórias. Ressalte-se ainda o predicativo atribuído ao gato que também diz respeito à natureza de independência e de liberdade dos gatos de um modo geral - viajado. Posteriormente ao encontro supramencionado registra-se:

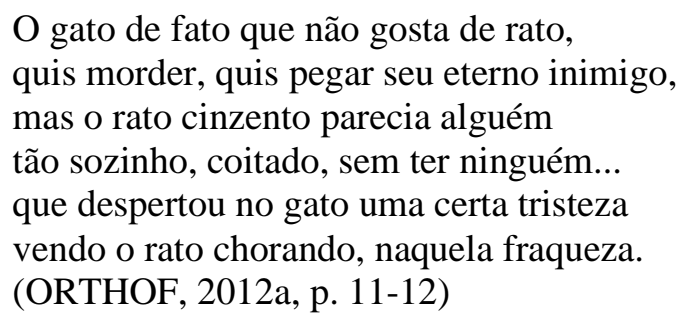

$\mathrm{O}$ gato de fato que não gosta de rato, quis morder, quis pegar seu eterno inimigo, mas o rato cinzento parecia alguém tão sozinho, coitado, sem ter ninguém... que despertou no gato uma certa tristeza vendo o rato chorando, naquela fraqueza. (ORTHOF, 2012a, p. 11-12) 


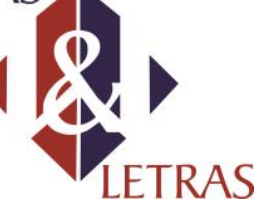

Os versos transcritos revelam a natureza relacional dos eternos inimigos. Câmara Cascudo (2000, p. 295-296) em Contos tradicionais do Brasil no conto etiológico "Por que o cachorro é inimigo do gato... E o gato do rato" registra que houve um tempo em que todos os animais eram amigos e o leão governava a todos. Um dia, Nosso Senhor mandou o leão libertar os bichos para que pudessem transitar livremente. O gato foi incumbido de entregar a carta do cachorro. No entanto, no caminho a convite do rato fez uma parada para beber mel e acabou dormindo. O rato curioso mexeu na bolsa do gato e acabou rasgando o papel. Quando o gato entregou o documento ao destinatário, este ficou furioso porque não pôde provar ao homem sua condição de bicho-livre e deu uma carreira no gato. O gato, por sua vez, sabendo que aquilo fora culpa do rato correu para vingar-se. E até hoje, a rixa permanece.

Entretanto, em Gato pra Ca, rato pra lá a rixa cede espaço para o sentimento de compaixão que o rato desperta no gato, assinalando, assim, mais uma quebra de expectativa distintiva da escritura orthofiana. Interessante notar que os animais não falam como se fossem seres humanos. A esse respeito, Lucille Desblanche (2011, p. 295-314) em "As vozes dos bichos fabulares: animais em contos e fábulas" aponta que La Fontaine no prefácio de suas fábulas registra que tais textos não se resumem a uma moralidade, mas que propiciam outros conhecimentos e que as peculiaridades dos animais e suas distintas naturezas estão delineadas nas fábulas. Em seu Discours à Madame de La Sabliére, o fabulista francês manifesta suas severas restrições à visão mecanicista de Descartes sobre os animais.

Assim, o gênero fabulístico foi planejado, portanto, para tornar os animais visíveis em textos que sugerissem relações constitutivas com eles. Nesse sentido, a despeito de cientistas e filósofos que demonstravam desrespeito pelos animais, La Fontaine pretendeu apresentar os animais às crianças em seu estado natural. Desse modo, a fábula deveria explicar o que é, por exemplo, um leão ou uma raposa e o motivo pelo qual, às vezes, um homem poderia ser comparado a tais animais. Além disso, a escritura fontainiana pretendeu questionar as fronteiras entre animalidade e humanidade e não somente ilustrar a superioridade humana sobre as demais criaturas, conforme Desblanche.

Ainda sobre a linguagem, Jacques Derrida (2011) em $O$ animal que logo sou questiona os conceitos de humanidade e animalidade. A reflexão inicia-se a partir do olhar lacaniano do gato de estimação que observa o filósofo francês desnudo em certo 


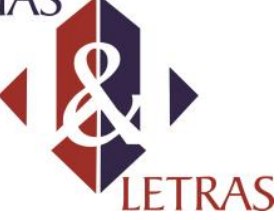

momento de sua intimidade. $\mathrm{O}$ incômodo suscitado por esse olhar inopinado origina em Derrida a necessidade de uma apreciação revisionista dos discursos filosóficos acerca dos animais "de Aristóteles a Heidegger, de Descartes a Kant, Levinas e Lacan" (DERRIDA, 2011, p. 54 e 83).

Os referidos discursos apresentam uma inegável convergência — ao animal falta a linguagem. Eis a justificativa ao conceito de homem que foi forjado e consolidado através dos séculos, eis o limite embasado sob um ponto de vista unilateral, o humano, da distinção entre o homem e o que ele nomeia como animal o qual se sustenta na convicção de uma falha: ausência da palavra ao animal. No entanto, de acordo com o pensamento derridiano, o mutismo do animal deve-se à tristeza de ser nomeado

Há muito tempo, é como se o gato se lembrasse, como se ele me lembrasse, sem dizer uma só palavra, o relato terrível da Gênese. Quem nasceu primeiro, antes dos nomes? Quem viu chegar o outro em seu território, há muito tempo? Quem terá sido o primeiro ocupante, e, portanto o senhor? O sujeito? Quem continua, há muito tempo, sendo o déspota? (DERRIDA, 2011, p. 39)

(...) Segundo a hipótese dessa espantosa inversão, a natureza (e a animalidade nela) não é triste porque muda (weil sie stummist). É pelo contrário a tristeza, o luto da natureza que a torna muda e afásica, que a deixa sem palavras (Die Traurigkeit der Naturmacht sie verstummt). Pois aquilo que, há muito tempo, torna triste, e em seguida priva o enlutado de suas palavras, aquilo que lhe interdita a palavra, não é um mutismo e a experiência de um não-poder, de um absolutamente não nomear, é sobretudo receber o nome. (DERRIDA, 2011, p. 42)

Conforme Derrida, (2011, p. 87) a palavra animal não passa de uma besteira reducionista. Para suprir a lacuna de uma palavra mais apropriada que abrangesse a multiplicidade de viventes "cuja pluralidade não se deixa reunir em uma figura única de animalidade simplesmente oposta à humanidade", cunhou o termo animot que designa não uma espécie, gênero ou indivíduo, antes se trata de "uma irredutível multiplicidade vivente. Para o filósofo francês, deve-se repensar a linha que separa humanidade dos demais seres, a ausência da palavra aos animais precisa ser apreciada de outra forma que não mera privação. A categorização sugere violência abalizada pelo desejo de inserção do múltiplo e do diverso em ordens insustentáveis elaboradas com a finalidade de redução, simplificação, apreensão e prisão de um ser.

Guimarães Rosa em "Quemadmodum”, crônica de Ave, palavra descreve a aparição de um misterioso gato - "Vá fosse um vulgar, sem ornato, gato de sarjeta. Porém, não: todo de lenda, de origem - corpo leonino, a barba cerimonial, rosto quase humano - formulador de pergunta." (ROSA, 2009, p. 1044). O "gato gris" surge no 


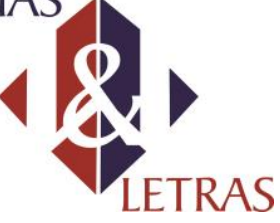

começo da noite e enigmático olha para o cronista. Assim como o olhar do bichano que mirou o filósofo francês remete a uma reflexão, o mesmo ocorre com o escritor brasileiro, conforme explicita o fragmento abaixo.

...Me olha, enrevesadamente, o máximo de pupilas, onde a aflorar sua forma informante. - 'Ajuda-te um pouco menos, para Deus poder te ajudar!' - há-de dizer-me, com sua fala de xamã em transe.

Disse? Não, nenhum miauitar. O prato lambido, o leite que bebeu, seu queixo peludo sujo de gotas, infantil, do mudo muito menino. Cerra e cerro os olhos. O horizonte é o fechado de uma pálpebra. Tomos somos amnésicos! O passado é uma coleção de milagres. O nunca é o sempre, escondido às nossas costas? Embruxeime. E ei-lo, confabulatório, felisomem. Tenta viver uma história, e já não mais consegue: ignora o tempo - evadiu-se de personagem. Transcende qualquer trama ou enredo, tranpôs essa corriqueira precisão. O que ele faz - é propor o enigma. (ROSA, 2009, p. 1045)

Reportando a Derrida os olhos do gato falam, "sem dizer uma só palavra". Talvez a falta, a falha não esteja na animalidade, mas na humanidade - "Todos somos amnésicos!"? Encontramos na escritura de Sylvia Orthof momentos reflexivos a respeito dos olhos do gato. Em História engatada, "o gato e a gata se viram e miaram /subiram nas casas miando... e gostaram /casaram de noite como os gatos se casam." A partir do olhar dos bichanos ocorre a movimentação da trama. Algo análogo acontece em Gato pra cá, rato pra lá, pois a partir do olhar do gato sobre o rato movimenta-se o enredo. Importante enfatizar que a interação entre tais seres ocorre à revelia do homem que não participa em nenhum momento tanto em Gato pra cá, rato pra lá como em História engatada. Essa não participação poderia refletir o distanciamento do homem das demais criaturas pautado em uma mentalidade de superioridade apenas questionada muito recentemente. Portanto, a própria fala do animal fabular assumindo, assim, características humanas com o objetivo único de reificá-los conduz ao aprisionamento, redução e empobrecimento desse ser.

Dona Lua, redonda, que a tudo assistia,

Viu o rato sofrendo, naquela agonia,

Saiu de lá do alto da sua morada,

Desceu cá pra perto, chegou apressada,

Usando, de prata, uma escada rolante,

Pousou no telhado a lua brilhante.

(ORTHOF, 2012a, p. 15)

Sylvia Orthof, adotando um caminho avesso às reificações, elege a personificação como figura para apresentar as ações da lua, todavia a caracterização fala 


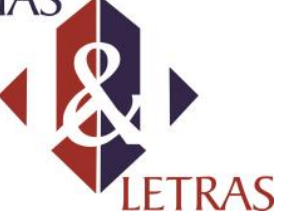

mais do ser tornado animado do que do humano. Nesse contexto, o processo de antropomorfização em Gato pra cá, rato pra lá referentes à tristeza do gato, ao choro do rato e à intervenção da lua adquire um grau mais acentuado. Igualmente, em História engatada tal processo se repete, e talvez em menor grau, pois os gatos agem como tais. Assim, as palavras para descrever tais ações personificam seus atos, tais como "casaram de noite / como os gatos se casam".

$\mathrm{O}$ antropomorfismo consiste em um processo mental utilizado para lidar com agentes não humanos encontrado em diversas culturas, bem como um recurso mitológico, religioso e literário que possibilitaria uma maior proximidade entre seres humanos ou não humanos tornando o ambiente mais inteligível. Tal fato poderia advir de que o homem tende a considerar os animais não humanos como meros elementos para atingir um determinado intento - alimentação, transporte, vestuário ou conforto psicológico. Trata-se de uma tendência em considerar o mundo e suas criaturas como disponíveis ao serviço humano aliada à estratégia cognitiva de extensão da caracterização humana para compreendê-los, apreendê-los e, por fim, controlá-los.

Os gatos de História engatada e Gato pra cá, rato pra lá não possuem casa ou dono e estão livres de quaisquer limitações impostas pelos humanos quando estes animais se transformam em de estimação, tais como confinamento, seleção artificial ou castração. A heterogeneidade do simbolismo do gato historicamente oscila entre tendências conflitantes em virtude da ambígua atitude deste felino - suave e distante. Também distante estava a lua em Gato pra cá, rato pra lá até ver a triste condição em que se encontrava o ratinho e resolver atuar. Desse modo, a narrativa encaminha-se para a finalização:

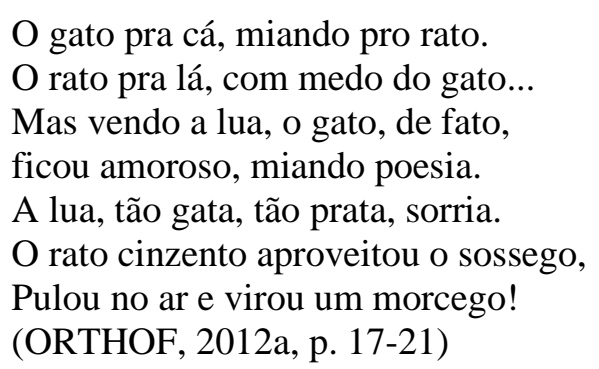

Em Che cos'e la poesia?, Derrida (2003) tece considerações acerca da poesia, assim como discorre sobre a origem e a finalidade do fazer poético. Para responder ao questionamento que intitula a obra, o filósofo, inicialmente, pede ao leitor que renuncie ao saber sobre poesia, sacrifício necessário para a compreensão da resposta apresentada. 


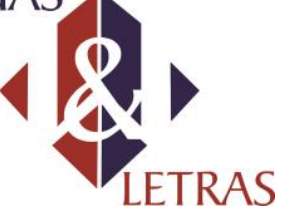

Na suposta conceituação do gênero poético, Derrida refere-se, metaforicamente, ao ouriço, animal mamífero que possui o corpo coberto de espinhos em seu dorso.

Trata-se, então da morfologia do ouriço em comparação com a poesia, definida como algo complexo, envolto em si mesmo, mostrando-se e recolhendo-se quando tocado. A partir dessa imagem, dois axiomas, interdependentes, concernentes ao poético, são apontados. O primeiro deles diz respeito à economia da memória, já que um poema deve ser breve. O segundo axioma, atinente ao coração, refere-se, por sua vez, à expressão "aprender de cor", aprender com o coração. Consequentemente, compreendemos a complexidade da poesia e do poético na aceitação de que a poesia é um acontecimento de linguagem que nunca permite ser lido ou traduzido em sua plenitude.

Deste modo, Derrida também pontua sobre o fazer poético, comparando-o a um acidente que deixa o ouriço vulnerável, colocando sua vida em risco, mas também, levando-o a defender-se. Sendo assim, afirma que "não existe poema sem acidente, não existe poema que não se abra como uma ferida, mas também que não cause ferimento". A palavra "acidente" também alude ao modo imprevisto como o poema é elaborado, pois, segundo o autor, o processo de criação poética é natural, espontâneo, sem que haja a necessidade de fórmulas, ou, metaforicamente falando, o ouriço não deve estar submetido ao adestramento.

Nessa conjuntura, a poesia de Gato pra cá, rato pra lá abre uma ferida, reportando à expressão de Derrida, na forma habitual de apreensão do mundo que admite somente uma resposta. O desfecho da fábula poética aponta para outro caminho possível, longe de preconceitos, estereótipos, do já sabido, do repetido, aponta ainda para o encontro de um novo modo de viver ou ver talvez mais inquieto, anárquico, pouco trilhado, menos comportado. O desfecho também evoca à crônica-fábula-poética de Guimarães Rosa "Circo do mundinho" pelo fato de possuir uma intervenção externa que modifica a narrativa.

Em Orthof, a lua intervém para deixar o gato mais amoroso, já em Rosa, o cronista intervém e salva a cigarra das leves garras de Xizinha. O desfecho também surpreende, pois em Orthof o rato se transforma em morcego, já em Rosa a cigarra interage com o cronista de modo insólito. Ambos os textos apresentam uma concepção em que as criaturas, sejam humanas ou não humanas, se relacionam de um modo não hierárquico. 


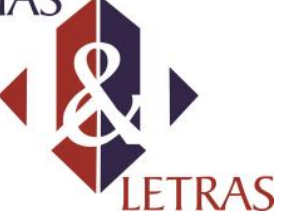

Finalmente, evidencie-se com Abramovich (1999, p. 59) que "o humor de Sylvia é inesgotável!!! Sua cabeça livre, sem viseiras, faz com que tudo ganhe vida, com que tudo ande fora dos trilhos, para descobrir caminhos por onde passam os trens”. Poderia acrescentar-se que além do humor, a sensibilidade de Sylvia é inesgotável. De fato, as trilhas picadas por Orthof apontam para o deslimite, pois oferecerem-se a distintas interfaces ao dialogar com textos da literatura, da poesia, da ecocrítica, da filosofia, da poesia, e outros.

\section{CONSIDERAÇÕES FINAIS}

Por fim, História engatada e Gato pra cá, rato pra lá adotam a subversão, pois ressaltam a fluidez e a transferência de traços entre homens e animais, são verdadeiros textos zooliterários que podem ser compreendidos como uma troca constante entre os dois polos até a conversão final e radical do olhar animal sobre o humano. Tais narrativas tendem a relacionar o homem e o animal de modo imbricado numa rede de diferentes interconexões.

Textos planejados para tornar os animais mais visíveis e cujas escrituras pretendem questionar as fronteiras entre tais seres e não somente ilustrar a superioridade humana sobre as demais criaturas. Constituem-se ainda como textos desconstrutores quanto à representação tradicional da questão animal examinada, por exemplo, por Jacques Derrida. Sobre o aspecto desconstrutor, Sylvia Orthof, enquanto herdeira de Monteiro Lobato, abraça o humor e a mensagem descondicionada, "sem viseiras". Sua obra funciona como um alerta acerca da revisão sempre possível de posições e ideias há tempos estabelecidas e seguidas.

Ou ainda, a escritura orthofiana por ter em grande conta o leitor infantil, oferecelhe a reflexão. Além disso, o tratamento original do tema proporciona diversos diálogos com outras artes e/ou ciências. Nesse artigo destaca-se a zooliteratura. No interior desse campo, desfila o gato, signo de suspeição e ruptura, como atesta a altiva estirpe felina composta por Mestre Gato, Gato Cherschire e Gato Malhado. Os gatos das narrativas de Sylvia Orthof juntam-se a estes e a outros desafiadores bichanos que com seus olhares confabulatórios transcendem tramas, enredos e propõem. 


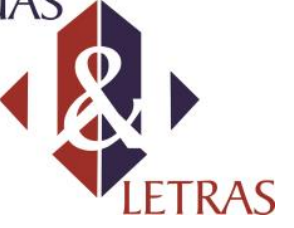

\section{REFERÊNCIAS}

ABRAMOVCH, Fanny. Literatura infantil - gostosuras e bobices. 5 ed. São Paulo: Scipione, 1999.

CABRAL Márcia Andrade Morais. Semiótica e argumentação: análise das obras de literatura infantil de Sylvia Orthof. (tese) Rio de Janeiro: Universidade Federal do Rio de Janeiro, 2017.

CASCUDO, Câmara. Contos tradicionais do Brasil.14 ed. Rio de Janeiro: Ediouro, 2000.

CHEVALIER, Jean e GHEERBRANT, Alain. [com a colaboração de, André Barbault ... [et al.] Dicionário de símbolos: mitos, sonhos, costumes, gestos, formas, figures, cores, números. Tradução de Vera da Costa e Silva ... [ et al.]. 24. ed. Rio de Janeiro: José Olympio, 2009.

COELHO, Nelly Novaes. COELHO, Nelly Novaes. Literatura infantil- teoria, análise, didá- tica. São Paulo: Ática, 1991.

DERRIDA, Jacques. O animal que logo sou. Tradução de Fábio Landa. São Paulo: UNESP, 2011.

. Che cos'e la poesia? Tradução de Osvaldo Manuel Silvestre. Coimbra: Angelus Novus, 2003.

DESBLANCHE, Lucille. "As vozes dos bichos fabulares: animais em contos e fábulas. In: MACIEL, Maria Esther. Pensar/escrever o animal - ensaios de zoopoética e biopolítica. Organização. Florianópolis: Editora da UFSC, 2011.

ORTHOF, Sylvia. Gato pra cá, gato pra lá. Ilustrações de Graça Lima. Rio de Janeiro: Rovelle, 2012a. 2012b.

Uma história de telhado. Ilustrações de Ivan Zigg. Rio de Janeiro: Rovelle, 2000.

História engatada. 2 ed. Ilustrações de Eva Furnari. São Paulo: Editora Braga,

O sapato que miava. 2 ed. Ilustrações de Ivan Zigg. São Paulo: FTD, 2007.

Os bichos que tive - memórias zoológicas. 2 ed. Ilustrações de Gê Orthof. São

Paulo: Moderna, 2004.

ROSA, João Guimarães. “Ave, palavra”. In: Ficção completa. Organização de Eduardo

Coutinho. 2 ed. Rio de Janeiro: Nova Aguillar, 2009. v 2.

Data de recebimento: 23/06/2019

Data de aprovação: 23/08/2019 